\title{
GATC Methylation by Dam methylase in archaea: its roles and possible transcription regulation by an FFRP
}

\author{
By Hideaki Korke, ${ }^{*}$ Katsushi Yoroyama, ${ }^{*}$, **) Tsuyoshi Kawashima, $\left.,{ }^{*}, * *\right)$

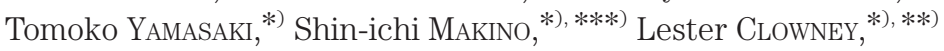 \\ and Masashi SuzuKI $\left.{ }^{*}\right), \dagger$ \\ (Communicated by Masanori OtsuKa, M. J. A.)
}

\begin{abstract}
Methylation of pairs of adenines at their N6 positions in GATC sites (GATC methylation) in archaeal genomic DNAs has been studied. Genomic DNAs in cells of three archaeal species were found as fully methylated, while those of four other archaeal species were free of such methylation. Consistently with this pattern of the presence or absence of GATC methylation, homologues of $E$. coli Dam methylase was found present or absent, but various other types of DNA methylases were not. A Dam homologue from Pyrococcus sp. OT3 was expressed and its expected function of methylating GATC was confirmed. By methylation of each adenine the DNA duplex was destabilized by $0.56 \pm 0.10 \mathrm{Kcal} / \mathrm{mol}$, and this effect was additive. For some archaea, transcription regulation of Dam methylase gene appears to be needed upon cell replication, and in regions upstream of three Dam methylase genes, nucleotide sequences close to TTTTCTTTGAAAA were present. This arrangement, five bases each at the ends, which are complementary to each other, sandwiching three $\mathrm{T}$ bases at the center, fits into a pattern the same as those recognized by dimers of transcription factors, feast/famine regulatory proteins (FFRPs).
\end{abstract}

Key words: DNA Methylation; DNA melting; DNA replication; thermophiles; transcription regulation.

Introduction. The presence of methylated adenine bases in $E$. coli cells was reported nearly half a century ago. ${ }^{1)}$ Now it is known that at GATC sites of the genomic DNA molecules in $E$. coli cells replicating, two adenine bases, A of GATC and another A complementary to T of GATC, are methylated at their N6 positions by Dam methylase ${ }^{2)}$ : see reviews. ${ }^{3)-10)}$ Such GATC sites are abundant around the replication origin, and methylation of GATC sites decreases the melting temperature of the genomic DNA. ${ }^{11), 12)}$ After replication, in each doublestranded DNA, only the strand inherited from the original DNA remains methylated, and the complementary strand newly synthesized is yet unmethylated until the cell initiates another cycle of replication. Such hemi-

\footnotetext{
*) National Institute of Advanced Industrial Science and Technology (AIST), AIST Tsukuba Center 6-10, Higashi 1-1-1, Tsukuba, Ibaraki 305-8566, Japan.

**) Japan Science and Technology Agency (JST), Core Research for Evolutionary Science and Technology (CREST), Honmachi 4-1-18, Kawaguchi Center Building, Kawaguchi, Saitama 332-0012, Japan.

***) Present address: Venture Business Laboratory, Ehime University, 3 Bunkyo-cho, Matsuyama, Ehime 790-8577, Japan.

$\dagger$ Correspondence to: M. Suzuki.
}

methylation enables discrimination between the strands for, e.g., selecting the strand which should be corrected, if mismatching is found.

Similar GATC methylation has been reported for some archaeal species but for some others this type of modification is absent. ${ }^{13), 14)}$ A methylase coded in an archaeal phage is able to substitute for Dam methylase in E. coli. ${ }^{15)}$ However, as will be discussed in this paper, this type of enzyme is missing from archaeal genomes, and so in archaeal cells where such a phage is absent, another type of enzymes is expected to be methylating GATC sites.

We became interested in GATC methylation in archaea, when we were comparing the complete genomic sequence of the archaeon Thermoplasma volcanium, which we determined in $1999{ }^{16), 17)}$ with another genomic sequence of a closely related archaeon, Thermoplasma acidophilum, which was determined by another group in $2000 .{ }^{18)}$ In general, the thermal stability of DNA is affected by its G/C content and the number of GATC sites methylated. In the two species living at very similar temperatures, $\sim 60{ }^{\circ} \mathrm{C}$, with increasing the $\mathrm{G} / \mathrm{C}$ content from $40 \%$ in $T$. volcanium to 
Table I. The presence or absence of in vivo GATC methylation and Dam methylase, and the number of GATC sites in archaeal genomes.

\begin{tabular}{|c|c|c|c|c|c|c|c|c|c|}
\hline $\begin{array}{l}\text { Archaeal species } \\
\text { (ref. of genomic } \\
\text { sequences) }\end{array}$ & $\begin{array}{l}\text { GATC } \\
\text { methylation }^{\text {a) }}\end{array}$ & $\begin{array}{l}\text { Dam } \\
\text { methylase }^{\text {b) }}\end{array}$ & $\begin{array}{l}\text { GATC } \\
\text { number } \\
\text { total }^{\text {c) }}\end{array}$ & $\begin{array}{l}\text { GATC } \\
\text { number } \\
/ \mathrm{Kbps}^{\mathrm{d})}\end{array}$ & $\begin{array}{l}\text { GATC } \\
\text { observed }^{\text {/expected }}{ }^{\text {e) }}\end{array}$ & $\begin{array}{l}\Delta \Delta \mathrm{G}^{\mathrm{f})} \\
\text { Kcal } \\
/ \mathrm{mol}\end{array}$ & $\begin{array}{l}\mathrm{G} / \mathrm{C}^{\mathrm{g})} \\
\%\end{array}$ & $\begin{array}{l}\mathrm{OGT}^{\mathrm{h}} \\
{ }^{\circ} \mathrm{C}\end{array}$ & Mbs \\
\hline $\begin{array}{l}\text { Picrophilus torridus (39) } \\
\text { Thermoplasma }\end{array}$ & $\mathrm{ND}^{*}$ & + & 6281 & 4.05 & $\underline{122 \%}$ & 7537 & 36 & 60 & 1.55 \\
\hline $\begin{array}{l}\text { volcanium }(16,17) \\
\text { Thermoplasma }\end{array}$ & + & + & 7858 & 4.96 & $\underline{138 \%}$ & 9430 & 40 & 60 & 1.58 \\
\hline acidophilum (18) & + & + & 13010 & 8.31 & $216 \%$ & 15612 & 46 & 59 & 1.56 \\
\hline Pyrococcus sp. OT3 (24) & + & + & 6218 & 3.58 & $\overline{97 \%}$ & 7462 & 42 & 98 & 1.74 \\
\hline $\begin{array}{l}\text { Pyrococcus abyssi (35) } \\
\text { Pyrococcus furiosus (25) }\end{array}$ & $\begin{array}{l}\mathrm{ND}^{*} \\
-\end{array}$ & - & $\begin{array}{l}4134 \\
4323\end{array}$ & $\begin{array}{l}2.34 \\
2.27\end{array}$ & $\begin{array}{l}61 \% \\
62 \%\end{array}$ & $\begin{array}{l}0 \\
0\end{array}$ & $\begin{array}{l}45 \\
41\end{array}$ & $\begin{array}{r}96 \\
100\end{array}$ & $\begin{array}{l}1.76 \\
1.90\end{array}$ \\
\hline $\begin{array}{l}\text { Thermococcus } \\
\text { kodakaraensis (73) } \\
\text { Sulfolobus }\end{array}$ & $\mathrm{ND}^{*}$ & - & 4797 & 2.30 & $59 \%$ & 0 & 52 & 85 & 2.09 \\
\hline $\begin{array}{l}\text { acidocaldarius (ND*) } \\
\text { Sulfolobus shibatae }\end{array}$ & - & ND* & ND* & ND* & ND* & $\mathrm{ND}^{*}$ & $\mathrm{ND}^{*}$ & 75 & $\sim 2$ \\
\hline $\begin{array}{l}\text { (ND*) } \\
\text { Sulfolobus solfataricus }\end{array}$ & - & ND* & ND* & ND* & ND* & $\mathrm{ND}^{*}$ & $\mathrm{ND}^{*}$ & 75 & $\sim 2$ \\
\hline (26) & - & - & 7664 & 2.57 & $78 \%$ & 0 & 36 & 80 & 2.99 \\
\hline $\begin{array}{l}\text { Sulfolobus tokodaii (35) } \\
\text { Methanosarcina }\end{array}$ & ND* & - & 5325 & 1.99 & $65 \%$ & 0 & 33 & 80 & 2.69 \\
\hline $\begin{array}{l}\text { mazei }(74) \\
\text { Methanococcus }\end{array}$ & $\mathrm{ND}^{*}$ & - & 12017 & 2.93 & $78 \%$ & 0 & 44 & 37 & 4.10 \\
\hline $\begin{array}{l}\text { maripaludis }(40) \\
\text { Methanobacter }\end{array}$ & $\mathrm{ND}^{*}$ & + & 2952 & 1.78 & $58 \%$ & 3542 & 33 & 37 & 1.66 \\
\hline $\begin{array}{l}\text { thermoautotrophicus (32) } \\
\text { Methanothermococcus }\end{array}$ & $\mathrm{ND}^{*}$ & - & 6446 & 3.68 & $94 \%$ & 0 & 50 & 65 & 1.75 \\
\hline $\begin{array}{l}\text { jannashii (31) } \\
\text { Methanopyrus }\end{array}$ & $\mathrm{ND}^{*}$ & + & 253 & 0.15 & $5 \%$ & 304 & 31 & 85 & 1.66 \\
\hline $\begin{array}{l}\text { kandleri }(75) \\
\text { Archaeogobus }\end{array}$ & $\mathrm{ND}^{*}$ & - & 14168 & 8.33 & $236 \%$ & 0 & 62 & 98 & 1.70 \\
\hline $\begin{array}{l}\text { fulgidus (33) } \\
\text { Halobacterium }\end{array}$ & $\mathrm{ND}^{*}$ & - & 2471 & 1.13 & $29 \%$ & 0 & 49 & 83 & 2.18 \\
\hline halobium (27) & $(-)^{* *}$ & - & 11047 & 5.48 & $\underline{185 \%}$ & 0 & 68 & 37 & 2.01 \\
\hline $\begin{array}{l}\text { Aeropyrum pernix (34) } \\
\text { Haloarcula }\end{array}$ & $\mathrm{ND}^{*}$ & - & 3244 & 1.94 & $\overline{51 \%}$ & 0 & 56 & 95 & 1.66 \\
\hline $\begin{array}{l}\text { marismortui ( } 76) \\
\text { Nanoarchaeum }\end{array}$ & $\mathrm{ND}^{*}$ & - & 6564 & 2.10 & $61 \%$ & 0 & 62 & 37 & 3.13 \\
\hline equitans (77) & $\mathrm{ND}^{*}$ & - & 636 & 1.30 & $45 \%$ & 0 & 32 & 90 & 0.49 \\
\hline
\end{tabular}

a) the presence or absence of GATC methylation. ${ }^{\text {b) }}$ the presence or absence of the Dam methylase gene. ${ }^{c)}$ the numbers of GATC sites in the genome. ${ }^{\text {d) }}$ average numbers of GATC per 1,000 bps. ${ }^{\text {e) }}$ the numbers of d) divided by those expected from random combinations of the same numbers of A/T/G/C bases: those larger than $100 \%$ are underlined. ${ }^{\mathrm{f}}$ expected destabilization of the genomic DNA duplexes by GATC methylation, calculated by assuming that methylating each adenine will decrease the free energy by 0.6 Kcal.

${ }^{g}$ The $\mathrm{G} / \mathrm{C}$ contents of the genomes. ${ }^{\text {h) }}$ the optimum growth temperatures of the organisms. ND*: not determined. ( )**: adopted from Ref. 13.

46\% in T. acidophilum, the number of GATC sites increases from 7,858 in the former to 13,010 in the latter (Table I). This correlation can be explained, if GATC sites are fully methylated in these archaea upon replication, thereby counter-acting the G/C content thereby decreasing the melting temperature (Tm) of the genomic DNA to a higher extent in T. acidophilum.

In this paper, by combining different types of approaches, we will analyze various aspects of GATC methylation in archaea.
Results. Destabilization of DNA duplexes by GATC methylation. Position 6 of an adenine base is occupied by an $\mathrm{NH}_{2}$ group (Fig. 1). The proton in the cisposition forms a hydrogen bond to the partner $\mathrm{T}$ base, while the other in the trans-position is exposed to the solvent. It was proposed that methylation first took place by replacing the trans-proton, and the methyl group, when rotated into the cis-position, would break the hydrogen bond, thereby destabilizing the DNA duplex. ${ }^{19)-22)}$ 


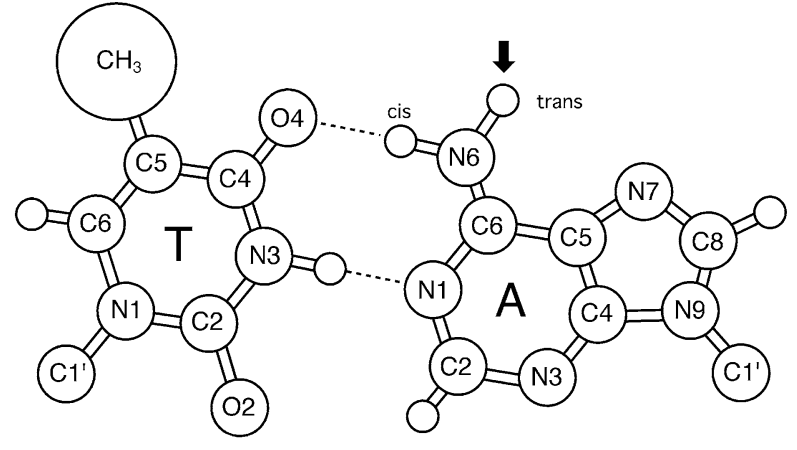

Fig. 1. Methylation of adenine at the N6 position. A methyl group is first introduced by replacing the proton at the trans-position (indicated by an arrow) and, when rotated into the cis-position, this methyl group breaks the hydrogen bond with the partner T base, thereby destabilizing the basepair.

Our experiments showed that the effect of methylating an adenine was essentially independent of the sequence and the position, and it was additive. A series of DNA oligomers were synthesized with or without incorporating methyl groups into adenines at their N6 positions (Table II). The melting temperatures of these DNA oligomers were determined by measuring circular dichroism or ultra violet absorption (Table II). When all the four adenines in two GATC sites were methylated, a DNA duplex (2 in Table II) was destabilized by 0.7 $\mathrm{Kcal} / \mathrm{mol}$ per each methylation: $\Delta \Delta \mathrm{G} / \mathrm{N}=-0.7 \mathrm{Kcal} / \mathrm{mol}$. Values of $\Delta \Delta \mathrm{G} / \mathrm{N}$ were similar, when one adenine base only in each GATC site was methylated (1 in Table II), $-0.6 \mathrm{Kcal} / \mathrm{mol}$, or when different numbers of adenines were methylated in different sequences, either in one of the two strands only or of both strands: $-0.56 \pm 0.10$ $\mathrm{Kcal} / \mathrm{mol}$. These values are close to those reported for a mixture of large DNA polymers, $0.35-0.95 \mathrm{Kcal} / \mathrm{mol}^{20}{ }^{20}$ Free energies of destabilizing archaeal genomic DNAs were calculated by assuming full methylation of GATC sites and a value of $\Delta \Delta \mathrm{G} / \mathrm{N}, 0.6 \mathrm{Kcal} / \mathrm{mol}$ (Table I).

The presence or absence of methylated GATC sites in archaeal genomic DNAs. We now describe identification of in vivo GATC methylation in archaeal genomic DNAs using a set of three restriction enzymes. ${ }^{23,13)}$ The three enzymes cleave DNA by recognizing the GATC sequence, with different sensitivities to the degree of methylation of the two adenines (Fig. 2c). Thus, Sau3AI is totally independent of the presence or absence of methylation, $D p n$ I cleaves the DNA only when both adenines are methylated, and MboI cleaves only when both adenines are free from methylation. In other words, if the DNA is digested by Sau3AI and DpnI but not by MboI, both adenines are methylated (Fig. 2c). Alternatively, if the DNA is digested by Sau3AI and MboI but not by $D p n I$, no adenine base is methylated. While if DNA is digested only by Sau3AI, only one of the two adenines is methylated.

In our experiments the genomic DNA of the archaeon Thermoplasma volcanium was digested by Sau3AI and DpnI but not by MboI (Fig. 2a). Thus pairs of adenines at GATC sites were methylated. Since no significant difference was found between the digest by Sau3AI and that by DpnI, and since MboI did not cleave this DNA even partially, all the GATC sites were fully methylated. The same pattern was observed with genomic DNAs of two other archaea, Thermoplasma acidophilum and Pyrococcus sp. OT3 (Table I).

In contrast, the genomic DNA of another archaeon, Sulfolobus acidocaldarius, was digested by Sau3AI and MboI only (Fig. 2b). No trace of digest was found, when it was treated with $D p n$ I (Fig. 2b). Thus, GATC sites in this DNA was totally free from methylation. The same type of patterns was obtained with other three species, Pyrococcus furiosus, Sulfolobus solfataricus, and Sulfolobus shibatae (Table I). In addition, our results confirmed the absence of GATC methylation in Sulfolobus acidocaldarius reported by another group. ${ }^{13)}$ The same group had reported the absence of GATC methylation in Halobacterium halobium. ${ }^{13)}$

Archaeal homologues of E. coli Dam methylase. Using genomic sequences of archaea, we identified homologues of $E$. coli Dam methylase from T. volcanium, ${ }^{16), 17)}$ T. acidophilum, ${ }^{18)}$ and P. OT3 ${ }^{24)}$ (Fig. 3a), but such a homologue was missing from P. furiosus, ${ }^{25)} \mathrm{S}$. solfataricus ${ }^{26)}$ and $H$. halobium. ${ }^{27)}$ This pattern coincided with another pattern of the presence or absence of GATC methylation described in the earlier subsection (Table I). The genomic sequences of the two other species, $S$. acidocaldarius and $S$. shibatae, remain undetermined. In the amino acid sequences of these archaeal homologues, blocks X and I-VIII (Fig. 3a) were identified in the order common among the $\alpha$ family of DNA methylases, ${ }^{28)}$ the same family where $E$. coli Dam methylase belongs.

The gene of a Dam homologue from $P$. OT3, pot0847421, was cloned and expressed using an E. coli system (see the band indicated by an arrow in Fig. 2e). From a cell extract this homologue was purified by four steps; heat treatment thereby removing the majority of the contaminating $E$. coli proteins, followed by ammoni- 
Table II. Destabilization of DNA duplexes by methylating adenine bases at their N6 positions

\begin{tabular}{|c|c|c|c|c|c|}
\hline No. & nucleotide sequence $^{\mathrm{a})}$ & $\begin{array}{c}\text { number of methylated } \\
\text { A bases [N] }\end{array}$ & $\begin{array}{l}\mathrm{Tm}^{\mathrm{b})} \\
\left({ }^{\circ} \mathrm{C}\right)\end{array}$ & $\begin{array}{c}\Delta \mathrm{Tm}^{\mathrm{c})} \\
\left({ }^{\circ} \mathrm{C}\right)\end{array}$ & $\begin{array}{c}\Delta \Delta \mathrm{G} / \mathrm{N}^{\mathrm{d})} \\
(\mathrm{Kcal} / \mathrm{mol})\end{array}$ \\
\hline 1 & CGATCGATCG/CGATCGATCG & +2 & $46.8 \pm 0.1$ & $-4.3 \pm 0.1$ & -0.6 \\
\hline 2 & CGATCGATCG/CGATCGATCG & +4 & $41.0 \pm 0.2$ & $-10.1 \pm 0.2$ & -0.7 \\
\hline 3 & CGATGCATCG/CGATGCATCG & +2 & $46.5 \pm 0.1$ & $-4.9 \pm 0.2$ & -0.6 \\
\hline 4 & CGTTCGAACG/CGTTCGAACG & +2 & $44.7 \pm 0.1$ & $-5.4 \pm 0.1$ & -0.7 \\
\hline 5 & CGTTGCĀACG/CGTTGC吕ACG & +2 & $44.6 \pm 0.2$ & $-5.8 \pm 0.2$ & -0.6 \\
\hline 6 & GCTGGGAAGAGC/GCTCTTCCCAGC & +2 & $49.8 \pm 0.2$ & $-4.8 \pm 0.2$ & -0.6 \\
\hline 7 & GCTGGAGGGAAGC/GCTTCCTCCAGC & +2 & $50.4 \pm 0.1$ & $-4.1 \pm 0.1$ & -0.5 \\
\hline 8 & GCTGÁGGAGAGC/GCTCTCCTCAGC & +2 & $51.6 \pm 0.1$ & $-3.6 \pm 0.1$ & -0.4 \\
\hline 9 & GCTAGGGĀGGAGC/GCTCCTCCTAGC & +2 & $49.5 \pm 0.1$ & $-4.6 \pm 0.1$ & -0.5 \\
\hline 10 & GCTÁGGGAGAGC/GCTCTCCCTAGC & +2 & $49.6 \pm 0.1$ & $-4.2 \pm 0.1$ & -0.4 \\
\hline 11 & GCTÁGAGAGAGC/GCTCTCTCTAGC & +1 & $47.1 \pm 0.1$ & $-2.3 \pm 0.1$ & -0.7 \\
\hline 12 & GCTA-AAGAGAGC/GCTCTCTCTAGC & +2 & $45.1 \pm 0.1$ & $-4.3 \pm 0.1$ & -0.6 \\
\hline 13 & GCTAGAAGAGAGC/GCTCTCTCTAGC & +3 & $44.0 \pm 0.1$ & $-5.4 \pm 0.2$ & -0.5 \\
\hline 14 & GCTÁGAGGAGGG/GCTCTCTCTAGC & +4 & $42.4 \pm 0.2$ & $-7.0 \pm 0.2$ & -0.5 \\
\hline
\end{tabular}

a) Adenines methylated are underlined. ${ }^{\text {b) }}$ The melting temperature of the DNA duplex in $20 \mathrm{mM}$ Na-phosphate buffer (pH 7.0) containing $100 \mathrm{mM} \mathrm{NaCl}$ and $1 \mathrm{mM}$ EDTA. ${ }^{c)}$ The difference between Tm's of the methylated and unmethylated forms of DNA duplexes. ${ }^{\text {d) }}$ The differences in the free energy values between the two forms divided by the numbers of methylated adenines.

um sulfate fractionation and ion exchange chromatography, and finally by hydrophobic chromatography. When the intact (i.e. unmethylated) form of the plasmid pUC18 ("dam" " in Fig. 2d) was treated with the purified archaeal enzyme, the DNA was found digested by Sau3AI and DpnI but not by MboI, showing now full methylation of pairs of adenines at GATC sites (compare "methylase treated" and "dam" in Fig. 2d). Here the intact and methylated forms of the pUC18 plasmid were prepared by introducing this plasmid, respectively, into the strains JM110 (dam $)$ and JM109 (dam $\left.{ }^{+}\right)$of $E$. $\operatorname{coli}^{29)}$ (Fig. 2d).

Methylase genes coded in archaeal genomes. We next carried out a more systematic search for DNA methylases coded in archaeal genomes. It is difficult to separate enzymes methylating adenines from those methylating cytosines solely by the sequences. Therefore, nucleotide sequences homologous to those of all the known methylases of either substrate specificity, which are collected in the REBASE database (http://rebase.neb.com/rebase/rebase.html), ${ }^{30}$ were searched using genomic sequences of T. volcanium, T. acidophilum, P. OT3, P. furiosus, S. solfataricus, $H$. halobium, Methanothermococcus jannaschii, ${ }^{31}$ Methanobacter thermoautotrophicus, ${ }^{32)}$ Archaeoglobus fulgidus, ${ }^{33)}$ Aeropyrum pernix, ${ }^{34)}$ Sulfolobus tokodaii, ${ }^{35)}$ and Pyrococcus abyssi. ${ }^{36)}$

The collected 61 amino acid sequences were submitted to cluster analysis. ${ }^{37,38)}$ Figure 4 is organized so that sequences more resembling are positioned nearer to each other. It is not easy to group these proteins into distinct sets. However, independently of the choice for narrower groups (e.g. I, II, III, IVa, b, Va-d, VIa, b, VII, VIII, IXa-c, X, XI) or wider groups (e.g. I-XI), only group II (i.e. Dam homologues) was found with the expected pattern: present in T. volcanium, T. acidophilum, and $P$. OT3, and absent from P. furiosus, S. solfataricus, and $H$. halobium. In this way, our identification of the type of methylases involved in GATC methylation discussed in the earlier subsection has been confirmed.

Another enzyme in group II, i.e. Dam, was identified to be coded in the genome of $M$. jannaschii. In addition, two more enzymes in this group were found in genomes sequenced recently, i.e. Picrophilus torridus ${ }^{39)}$ and Methanococcus maripaludis ${ }^{40)}$ (Fig. 3a).

The viral methylase M. $\phi$ Ch1-I ${ }^{15)}$ able to replace $E$. coli Dam methylase, was found to be the closest to group $\mathrm{X}$, but the homology was not significantly high; no homolog was found in the archaeal genomes. Group X corresponds to type $\beta$ in ref. 28 , groups I, II, and VII to type $\alpha$, and group XI to $\gamma$. Groups I, VII, and XI were found to be close to eubacterial enzymes functioning with partner restriction enzymes, I with HindII, VII with DpnII, and XI with DdeI.

Discussion. Possible regulation of Dam methylation by an FFRP. While analyzing regions upstream of the Dam methylase gene from $P$. OT3, we noticed a block of 35 bases (from the first $\dagger$ to the last $\dagger$ in Fig. 5a), 


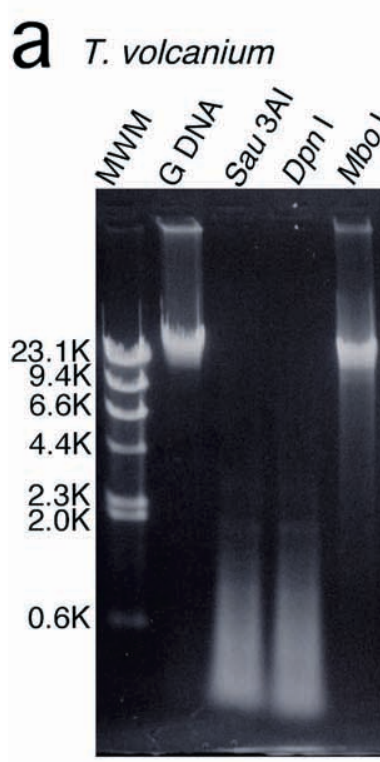

$b$

\section{S. acidocaldarius}

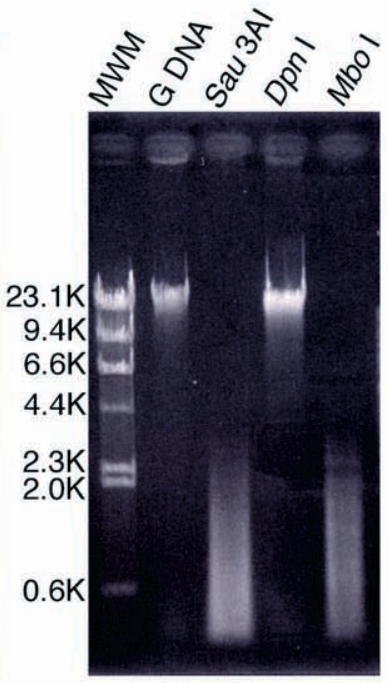

d

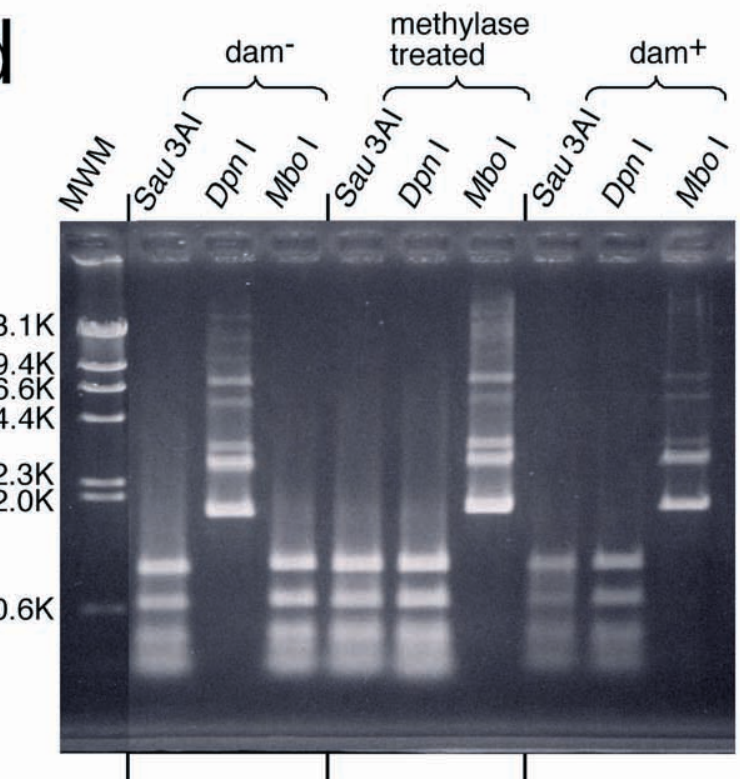

C

\begin{tabular}{|c|c|c|c|c|}
\hline \multirow[t]{2}{*}{ Enzyme } & \multirow{2}{*}{$\begin{array}{l}\text { Cleavage } \\
\text { sites }\end{array}$} & \multicolumn{3}{|c|}{ Number of methylated $A$} \\
\hline & & 0 & 1 & 2 \\
\hline Sau 3AI & $\begin{array}{l}\downarrow \text { GATC } \\
\text { CTAG } \uparrow\end{array}$ & 0 & 0 & 0 \\
\hline Dpn I & 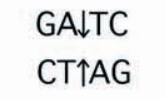 & $x$ & $x$ & 0 \\
\hline Mbol & $\begin{array}{l}\downarrow \text { GATC } \\
\text { CTAG } \uparrow\end{array}$ & 0 & $x$ & $x$ \\
\hline
\end{tabular}

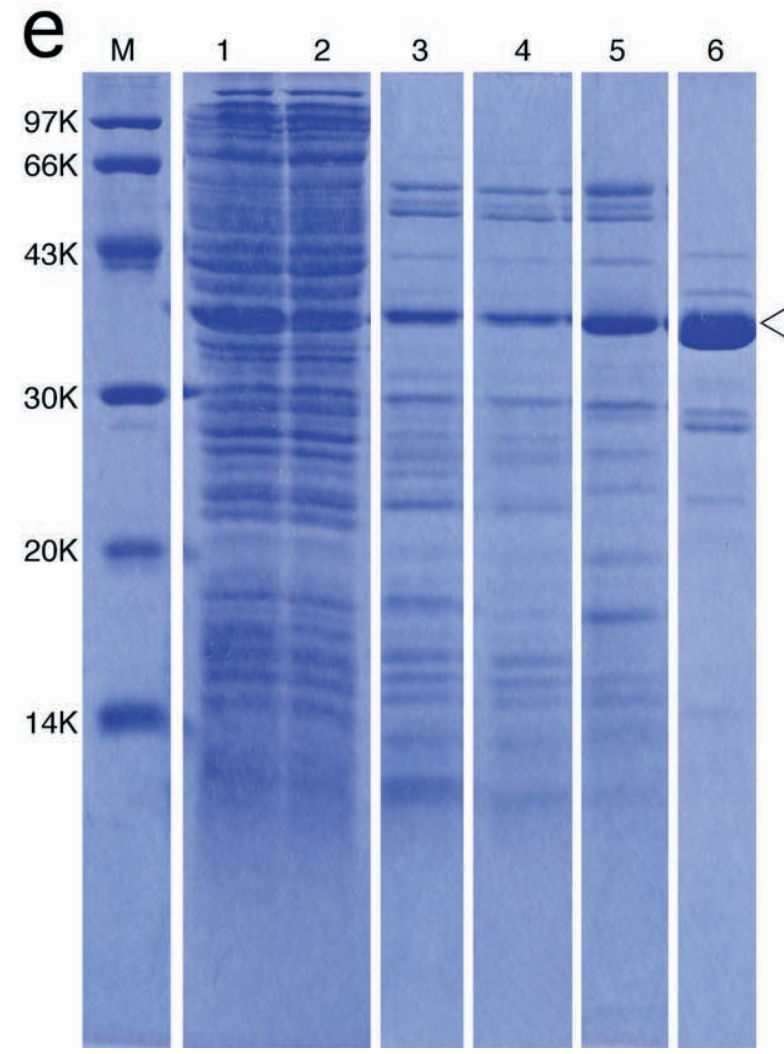

Fig. 2. Identification of the presence or absence of GATC methylation in genomic DNAs (a-c), and purification of archaeal Dam methylase mediating this modification (d, e). (a, b) Genomic DNAs of Thermoplasma volcanium (a) and Sulfolobus acidocaldarius (b) treated with three types of restriction endonucleases. The two genomic DNAs (G DNA) were incubated with Sau3A, DpnI, and MboI, respectively. MWM: molecular weight markers made by cleaving the $\lambda$ phage DNA with HindIII. Agarose gels, $1.0 \%$, were used for the electrophoreses. (c) The sites cleaved by the restriction enzymes (see arrows) and the sensitivities of the reactions towards degrees of methylation of the adenine bases. (d) Another 1.0\% agarose gel. Three lanes on the left (dam) show the unmethylated form of pUC18 treated, respectively, with Sau3AI, DpnI, and MboI. Three lanes in the center (methylase treated) show the unmethylated form of the pUC18 DNA incubated with P. OT3 Dam methylase (e, lane 6), and treated, respectively, with the three enzymes. Three lanes on the right $\left(\mathrm{dam}^{+}\right)$show the fully methylated form of pUC18 DNA treated, respectively, with the three enzymes. MWM: molecular weight markers. (e) A crude extract from $E$. coli cells expressing Dam methylase from P. OT3 (lane 1), the supernatant obtained after centrifugation of the crude extract (lane 2), the supernatant obtained after incubation at $70{ }^{\circ} \mathrm{C}$ for 30 min (lane 3 ), a fraction soluble in $20 \%$ saturated ammonium sulfate but precipitated by $70 \%$ saturated ammonium sulfate (lane 4), a fraction obtained by ion exchange chromatography with the $\mathrm{KCl}$ concentration 0.4-0.5 M (lane 5), another fraction obtained by subsequent hydrophobic affinity chromatography with the ammonium sulfate concentration 0.8-1 M, (lane 6), and molecular weight markers (M), subjected to electrophoresis using a sodium dodecyl sulfate-15\% polyacryl amide gel. 
a

TVG0884813 ta0676875 pot 0847421 mj0530503 mm0728799 EC Dam Mtase pt1086197

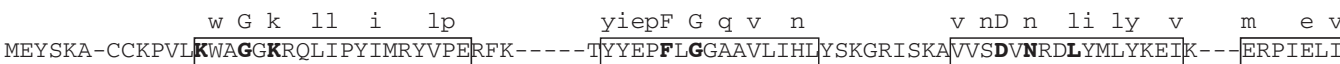
MEQSLAEYYRPILKWAGGKRQLLPILLKYSPAKFN-----TYYEPF IGGAALLISLYSLNKIKSAVVSDTNKDLYNLYKTMK-- - ENPLKLI - - - --MAEPVLKWAGGKRQILHYIVSLMPSDYKD---RRFHEPFFGGGAVTFWL EP-- - KEGTINDINPKLINFYIIIR---DYPEELI - - - - MEVKPFLKWAGGKTQILSQIEENLPKELKEGNIKKYIEPFVGGGAVLFYLLQKYEFKKVIISDINEDLMLCYKVVKNDVDRLIEEI - - -MHRKAKPFLKWAGGKRRLLTQFEDHYPEGLKNGKIKKYVEPFLGGGAVYLSLQSKYKFKKVVLNDINHELMLSYKTVQNNIDELISIL - - - MKKNRAFLKWAGGKYPLLDDIKRHLPKGEC-- - - LVEPFVGAGSVFLNTDF - - - SRYILADINSDLISLYNIVK-- -MRTDEYV - - - - - - MNILIKYPGSKGSLLNDIKDVFNRSSCS - - - RLVDVFGGSGIVLLNLDA- - - GEKIYNDINLDLINLFKTLK- --YKYNDLY

$$
\text { block X block I block II }
$$

TVG0884813 ta 0676875 pot 0847421 mj 0530503 mm0728799

EC Dam Mtase pt1086197
SVMR----SLNFQNKREDYYRARDLFNET------SDYKLR-------------SALLIYLNKHGYNG---LYRLNSLGLFNVPFGRHR AALK----DLKFKNNREDYYEARSLFNST-----EDPVKR------------SALLIYLNRHGYNG---LYRVNSENKFNVPFGRYS EDAK- - - - MHKNEREYYYRMRREYNKLALSSWFRDFVRRGFKVESEODRRNAIRLASLLLYLNKTAYNG-- -LYRENRKGEFNVPFGRYK SSLRDEFLSLDEEKRKEFYYKVRDDFNKNKND---CDEVKR-------------VAQFIFLNKTCYNG---LYRVNKKGEFNVPYGRYK KPIEENFNKMNFESQKMQYYKIRNEYNIEKSN---IDKNKSE--------NIIENVARFIFLNKTCFNG---LYRLNKKGMFNVPFGRYI

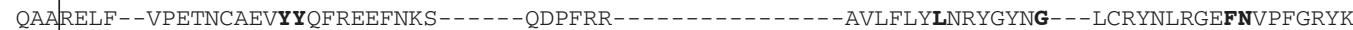
KMITALK----NREVFDYYKYNIDSMGK------NDVER------------AFKTFYLLNTTFGGQGNTYIKHDKSKFNLVSRIIN f $\quad d q \quad 1$ d $\quad 1 \quad$ f sn

TVG0884813 NTSFPSDODILSLSNMLSSCTILNEDFEKAVAGAE--SGDFVYFDPPYVPLSKTSNFTSYTESGFTHKDOVRLKDVFIETSN-RGVFVMETN ta 06768 pot 0847421 mj 0530503 mm0728799 EC Dam Mtas pt1086197 NPRMPSSENIMAFSNILKSCTILNLDFEMAVSHAT--AGDFVYFDPPYMPLNRTSYFTEYTNSGFDEKDQERLFRVYYELSK-RGVYVMESN NPRIVDEKRLREASRVLRNLEIYNTDFSYVLDKAK--BGDLVYFDPPYQPISQTASFTDYSKEGFTYKDQIRLRDVCLELHR-RGVYFILSN NPKIFDEONLKNVSKLLKNVKILCGDFEIVDEYVD--A ESFVYFDPPYKPLNKTSSFTSYTKYDFNDDDOIRLAKFYRKLDK-RGAKLMLSN RPRIFDEPTLRGVNKALKGVKLLCDDYKNVEKHISIDHETFVYIDPPYRPLPETVSFTSYSKEDFLEKDQVGLSNWFKYLDK-KGAYLMLSN e KPYFP-EAELYHFAEKAQNAFFYCESYADSMARAD--DASVVYCDPPYAPLSATANFTAYHTNSFTLEQQAHLAEIAEGLVE-RHIPVLISN

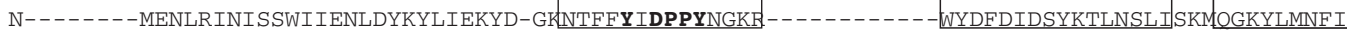
block IV block V block VI

TVG0 884813 ta0676875 pot 0847421 mj0530503 mm0728799

EC Dam Mtase pt1086197 rrv

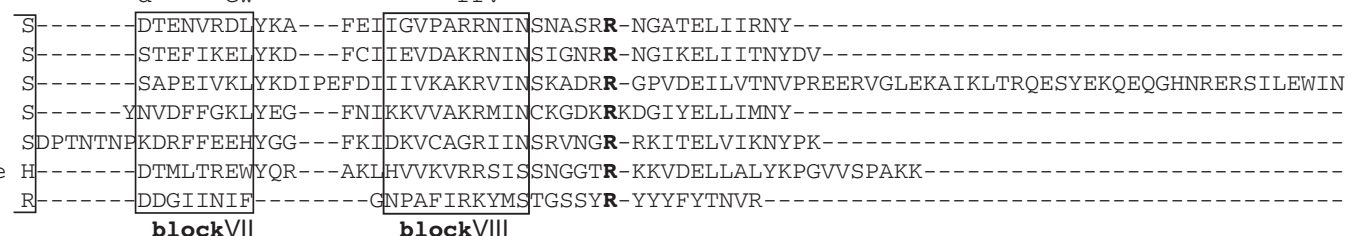

blockVIII

b

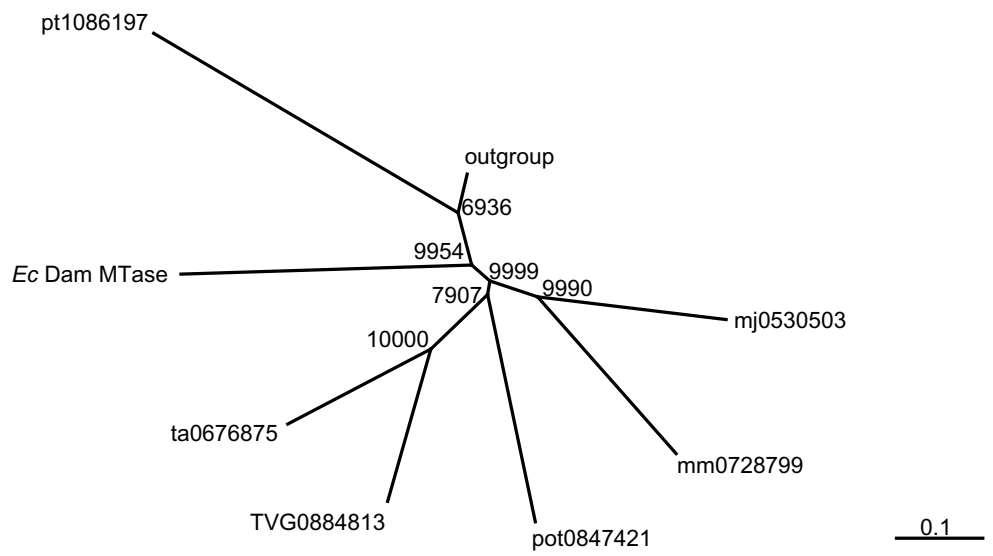

Fig. 3. Alignment of the amino acid sequences of E. coli Dam methylase and archaeal homologues (a), and a phylogenetic tree made using this alignment (b). (a) Blocks X and I-VIII are those common among the $\alpha$ type of DNA methylases. ${ }^{28)}$ Above the sequences residues fully conserved in the $\alpha$ type (upper-case letters) and others frequently found (lower-case letters) assigned by another group ${ }^{28)}$ are indicated. TVG: Thermoplasma volcanium. ta: Thermoplasma acidophilum. mj: Methanothermococcus jannaschii. pot: Pyrococcus sp. OT3. Ec: Escherichia coli. mm: Methanococcus maripaludis. pt: Picrophilus torridus. (b) Other types of DNA methylases from T. volcanium (see Fig. 4) are used as the outgroup. Bootstrap values were calculated per 10,000 trials. 


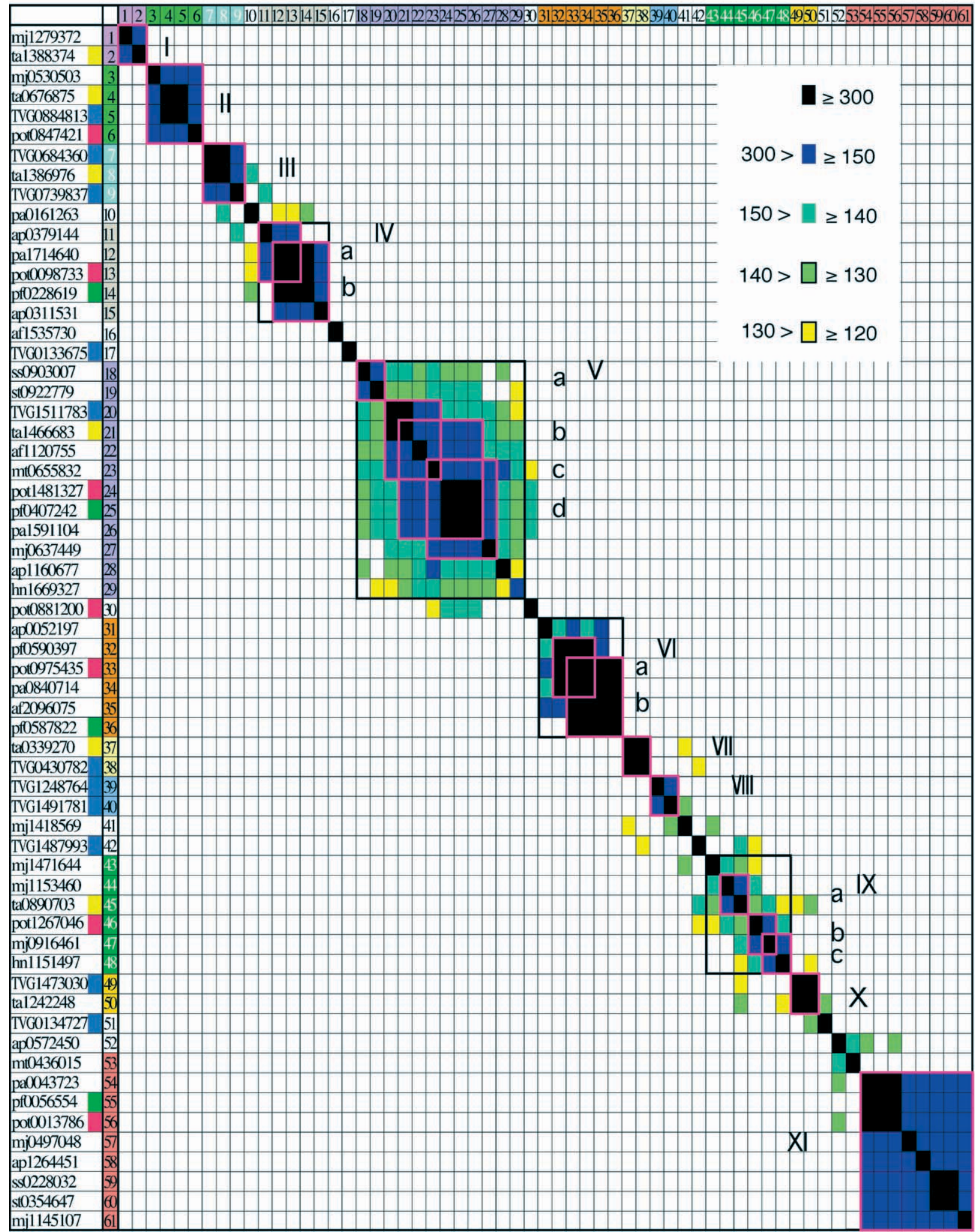

Fig. 4. A cluster plot of archaeal DNA methylases. Along the ordinate, next to gene identifications, small squares are drawn in colors to discriminate between the origins: P. OT3 (red), P. furiosus (green), T. volcanium (blue), and T. acidophilum (yellow). Entry numbers, 1-61 (ordinate and abscissa) are colored, thereby differentiating methylase groups I-XI. Inside the plot, the levels of Fasta Z scores relating pairs of entries are indicated using another color code (see inset). Inside a black box, entries have Z scores of 120 or higher to at least half of the other entries assembled together. Inside a red box all entries are related by Z scores of 150 or higher only (I, II, III, IVa, IVb etc.): sub-classification of the eleven larger groups in black boxes. 


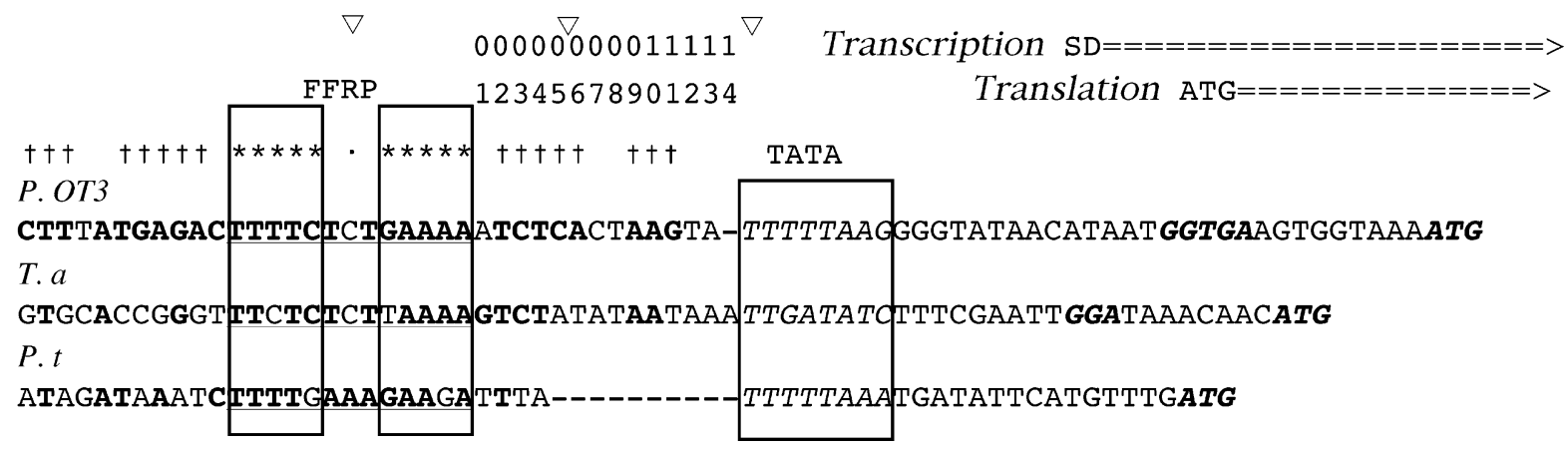

Fig. 5. Nucleotide sequences of the regions upstream of Dam methylase genes. P. OT3: Pyrococcus sp. OT3. T. a.: Thermoplasma acidophilum. P. t.: Picrophilus torridus. The types of bases occurring frequently at positions are highlighted in bold. Bases in the $P$. OT3 sequence in a reverse complementary arrangement, being related by the center $(\bullet)$, are labeled with $\dagger$ (farther from the center) or * (nearer to the center, also boxed). Three positions around the center are occupied by consecutive pyrimidines or purines. The 13 bps around the center are predicted to be recognized by an FFRP dimer (underlined). TATA boxes, SD signals, ATG start codons are indicated. Reverse triangles (top) indicate a 10.5 bp helical periodicity.

which was reverse complementary almost through the sequence. Similar sequences were found upstream of the Dam methylase genes from two other archaea, T. acidophilum and P. torridus (Fig. 5a). But such sequences were absent from $M$. jannaschii, $M$. maripaludis, and T. volcanium. The core of the consensus of the three sequences is TTTTCT[C/T]TGAAAA. Here, TTTTC and GAAAA at the two ends are complementary to each other, and the three bases at the center form a run of pyrimidines or, along the complementary strand, purines.

It is likely that these sequences are recognized by a transcription factor forming a dimer. The majority of known archaeal transcription factors fall into a single category, the feast/famine regulatory proteins (FFRPs). ${ }^{41-61)}$ And standard binding sites of FFRP dimers are summarized as $\mathrm{N}_{\mathrm{A}} \mathrm{N}_{\mathrm{B}} \mathrm{N}_{\mathrm{C}} \mathrm{N}_{\mathrm{D}} \mathrm{N}_{\mathrm{E}}$ TTTT $\mathrm{N}_{\mathrm{E}} \mathrm{N}_{\mathrm{D}} \mathrm{N}_{\mathrm{C}} \mathrm{N}_{\mathrm{B}} \mathrm{N}_{\mathrm{A}}$, where $\mathrm{N}_{\mathrm{A}}$ and $\mathrm{N}_{\mathrm{A}}$, e.g., are complementary to each other. The thirteen basepair sequence positioned upstream of the Dam methylase genes, TTTTCT[C/T]TGAAAA, fits well into this pattern, and thus it is likely that the dam promoters are regulated by an FFRP.

Candidates of FFRPS regulating the dam promoter. Since many FFRPs are coded in an archaeal genome, in order to identify FFRPs possibly regulating dam promoters, it is essential to understand the DNAbinding specificity of individual FFRPs. The FFRP whose DNA-binding specificity has been best characterized so far is $E$. coli Lrp (leucine-responsive regulatory protein) ${ }^{62)}$ Its standard binding site has been deduced as AGAATTTTATTCT. Using foot-printing experiments the binding sequence of another FFRP from $P$. OT3, FL11, has been deduced as TGAAAATTTTTCA ${ }^{56)}$ By re-interpreting foot-printing experiments published by another group, ${ }^{63)}$ we have identified the binding sequence of an FFRP from M. jannaschii, Ptr1, into a similar form, TACGCATTGCGTA. ${ }^{42)}$ In the asn promoter regulated by E. coli AsnC, a regular repeat of sequences close to TCATTTTTAATGA has been identified ${ }^{46)}$ It is likely that $5 \mathrm{bps}$ at either end of each sequence is recognized by an $\alpha$-helix of the $\mathrm{FFRP}^{46)}$ : the recognition helix (Fig. 6).

The amino acid sequences of the cores of the recognition helices of these four FFRPs are aligned (Fig. 6a). In general, amino acid positions in a DNArecognition helix can be classified to three types. ${ }^{64)-67}$ ) Those in type I face the opposite side of the DNA in order to interact with the rest of the protein domain mainly by hydrophobic contacts, thereby limiting the DNA-binding geometry: hydrophobic residues found at positions 1,5 , and 8 with an expected 3.6 periodicity (Fig. 6a). Amino acid positions in type II bind phosphate groups of the DNA, thereby fixing the binding geometry. Often Lys or Arg are used for this purpose: positions 4 and 7. An amino acid residue having opposite electron charges, e.g. Glu, is not expected at such a position. It is likely that positions $3,6,9$, and 10 are the those facing into the DNA major groove and contacting the bases: candidates for type III.

In each of subfigures b-i in Fig. 6 residues found at positions 3, 6, 9, 10 are shown along a line from the $\mathrm{N}$ terminus (left) to the C-terminus (right), except for f, 
a

\begin{tabular}{|c|c|}
\hline & 0000000001 \\
\hline & 1234567890 \\
\hline Lrp & CLERVE $\underline{R} L E R$ \\
\hline AsnC & I HVRVEKMKQ \\
\hline FL1 1 & I HER I R $\underline{K} L R E$ \\
\hline Ptr1 & VRN $\underline{R}$ VK $\underline{R} L T E$ \\
\hline
\end{tabular}

d AsnC

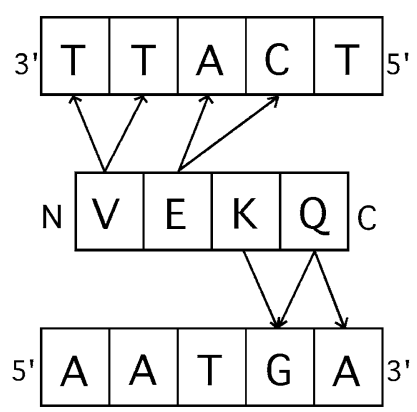

g FL3-dam promoter

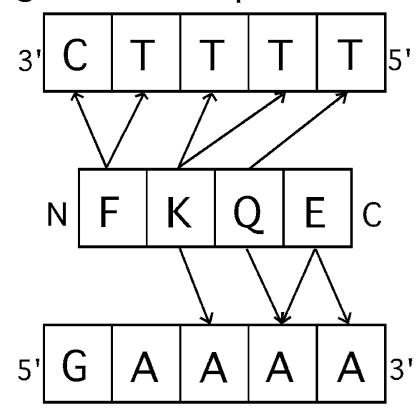

b Lrp

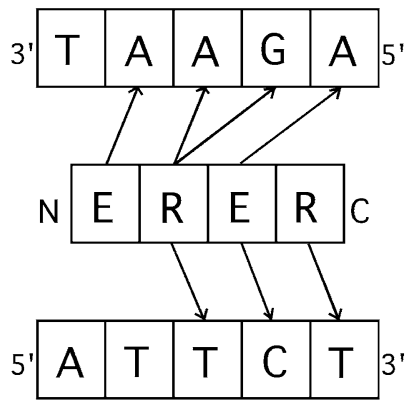

e Ptr1

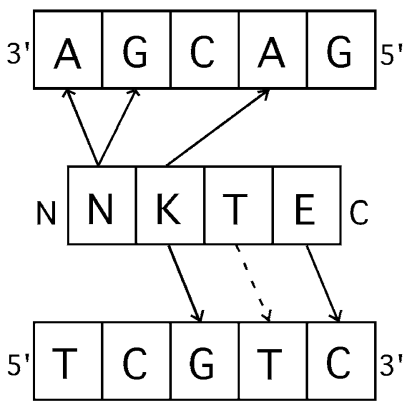

h FL8-dam promoter

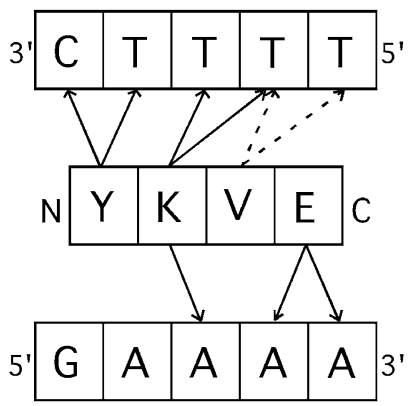

C FL11

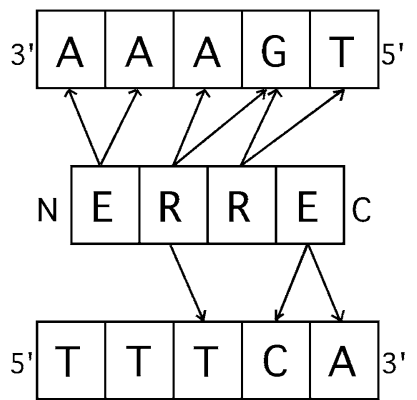

f summary of b-e

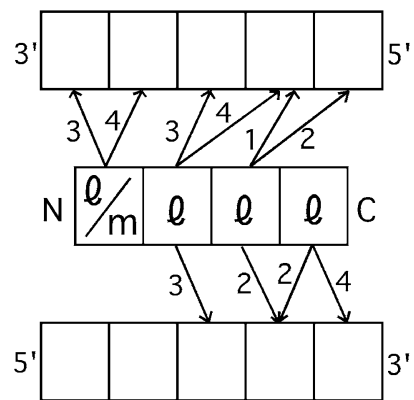

i FL1-dam promoter

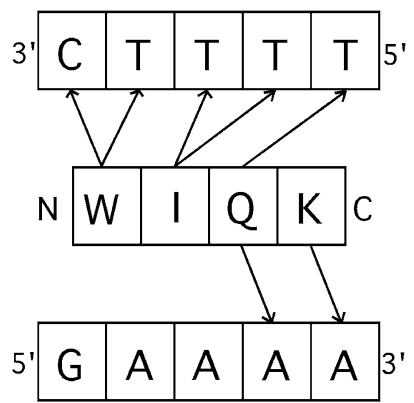

Fig. 6. Prediction of contacts between amino acid residues in FFRPs and DNA bases in promoters. (a) The amino acid sequences of the cores of DNA recognition helices in four FFRPs. Hydrophobic residues producing the same 3.6 periodicity are highlighted in bold (positions 1, 5, 8). Positions 4 and 7 are occupied by Arg or Lys only (underlined). (b)-(e) Prediction made for four FFRPs of known DNA-binding specificity. In each subfigure along the central line residues found at positions 3, 6, 9, 10 are shown from left to right. Above and below this line five basepairs recognized specifically by the FFRPs are shown. Bases in the top strand (running from right, 5', to left, 3') and those in the bottom strand (running from left, 5', to right, 3') are in pairs. Amino acid residues and bases, able to form chemical contacts, are connected, so that these would best produce the same contacting pattern (f). An amino acid residue, Thr, in Ptr1 (e) is able to contact any of the four bases, and it is a single small residue found at this position: its contacting position is unclear (shown by a broken line). (f) Accumulation of contacts shown in (b)-(e). Along the central line the large (l) or medium (m) sizes of the residues found are shown. Most of the amino acid residues found in the four FFRPs are large (l) except for Val and Asn, which are medium-sized (m). ${ }^{64)-67)}$ The contact from Thr in Ptr1 is not included. (g)-(i) Using the common contacting pattern (f), possible contacts to the dam promoter from three of the eleven FFRPs from $P$. OT3, FL3, FL8, and FL1, are predicted. Contacting positions of a medium size residue, Val, at position 9 in FL8 (h) is unclear (broken lines), since no residue of a similar size is found in the four examples (b-e) at this position. 
where sizes of the residues in b-i are shown (see next paragraph). Above and below this line, bases in the two DNA strands are drawn from 5' to 3' in directions opposite to each other, by looking into the major groove of the DNA. Amino acid side chains and the DNA bases can form chemical bonds, and some of them are specific, ${ }^{64)-67)}$ e.g., Arg (Lys) and G, Asn (Gln) and A, Val (or any hydrophobic residues) and $\mathrm{T}$, and Asp (Glu) and C. In Fig. 6b-e, residues and bases are connected, so that these would best produce the same contacting pattern (summarized in Fig. 6f).

Formation of these contacts depends also on the size of amino acid residues. A residue too small might not reach the target DNA base. While a residue too large might be unable to fit into the interaction surface. ${ }^{64)-67)}$ Most of the amino acid residues found at the four positions in the four FFRPs are classified as large (1) except for Val in (d) and Asn in (e), which are classified as medium (m), and another residue, Thr, in Ptr1 (e), which is small. Because of its ability to contact any of the four bases, the contacting position of the $\mathrm{T}$ is not clear (shown by a broken line in Fig. 6e).

Using the common contacting pattern (Fig. 6f), candidates interacting with the dam promoter have been narrowed from fifteen FFRPs coded in the genome to three, FL3, FL8, and FL1 (Fig. 6f-h). Of these, FL1 has Asn instead of Lys or Arg at position 7, and so it may adopt a different binding geometry.

Biological roles of Dam regulation. Factors, FFRPs, have two different modes for regulating transcription of genes. ${ }^{60)}$ When binding downstream of the TATA-box, these repress transcription. When binding immediately upstream of the TATA-box, as is the case for the Dam promoter (Fig. 5), they often activate transcription possibly by recruiting the initiation factor, the TATA-binding protein (TBP) to the TATA-box. In some archaeal species the Dam methylase genes might be expressing constitutively, so that the G:C contents and the number of methylated GATC sites are balanced, thereby producing appropriate Tm's. But in some other species, methylation of all the GATC sites might be too destabilizing, when cells are not replicating, and so finer regulation might be needed. Such a regulatory mechanism will benefits archaea, when the temperature outside is too high or too low, and so it needs to "sleep". Although $P$. OT3 is a hyper-thermophile and its optimum growth temperature is $\sim 100{ }^{\circ} \mathrm{C}$, it is doubtful if it could survive at much higher temperatures. On the other hand, it can survive in a refrigerator for weeks.

So far, we have found no indication for possible use of GATC methylation for regulating transcription of a gene in an archaeon. No GATC combination is found immediately upstream of the Dam methylase genes. In the genome of $T$. volcanium the frequency of GATC combinations found upstream of independent genes and operons is $4.12 / \mathrm{Kbps}$, which is slightly lower than that inside these units, $5.07 / \mathrm{Kbps}$. The density of GATC sites does not show any strong position dependence, and that around the putative replication origin is slightly lower than the average.

GATC Methylation and evolution of archaea. Another group has argued that the GATC methylation could have developed rather recently inside a particular subgroup of eubacteria and then propagated into various archaea independently. ${ }^{13)}$ However, this hypothesis is unlikely, since many aspects of a phylogenetic tree made by using the amino acid sequences of the Dam methylases (Fig. 3b) are consistent with standard views of evolution except that the Dam methylase from $P$. torridus is remote from the others in group II. It still satisfies requirements for this group, and it is closer to this group than any other methylases so far analyzed. In order to explain these facts, horizontal transfer may be a choice.

In many genomes where the Dam methylase gene is coded, the numbers of GATC combinations are larger than what are expected from random combinations of $\mathrm{A} / \mathrm{T} / \mathrm{G} / \mathrm{C}$ bases, and in genomes where the gene is missing, this combination is avoided ("GATC observed/expected" in Table I). In short, the number of this combination has increased in order to decrease Tm of the DNAs.

A notable exception for the above statement is $M$. jannaschii, which has Dam methylase but whose number of GATC is only $5 \%$ that expected. This extreme low frequency can be explained by its high optimum growth tempera ture in combination with its low G/C\% content. This and another methanobacterium, M. maripaludis, have similar G/C contents, 31\% and 33\%, respectively, but the OGT of the former, $85^{\circ} \mathrm{C}$, is much higher than that of the latter, $37^{\circ} \mathrm{C}$. While adapting to high temperatures, with keeping a Dam methylase, many GATC sites created might have been removed.

On the other hand, two other species have no Dam methylase but have GATC sites with high frequencies, i.e. $236 \%$ in M. kandleri and $185 \%$ in H. halobium. These high frequencies might be reminiscent of the methylation system once present in these organisms.

Materials and methods. Nucleotide sequence analysis. Genomic sequences of archaea were obtained 
from the NCBI database (http://www.ncbi.nim.nih.gov/). In this paper each gene is identified with two alphabets identifying the species (e.g. pf for Pyrococcus furiosus) followed by the position of the stop codon using the numbering scheme in the NCBI database, except for genes of Thermoplasma volcanium and Pyrococcus sp. OT3, which are identified using their codes (e.g. pot0847421 and TVG0884813) in our ARCHAIC database (http://www.aist.go.jp/RIODB/archaic/).

Homology searches of genes were carried out by using the FASTA program ${ }^{67)}$ on translated amino acid sequences. Using the scores obtained, sets of homologues were identified by a method. ${ }^{68)}$ Cluster analysis was carried out using the PAM program in a package $\mathrm{R}$ (http://www.r-project.org/), ${ }^{69)}$ and Fasta Z scores,${ }^{70)}$ and by further improving the results manually. Analysis of phylogeny was carried out using the ClustalW ${ }^{65)}$ program and translated amino acid sequences.

Archaeal strains used for the experimental study. These strains were obtained from Japan Collection of Microorganisms (JCM), and the standard protocols supplied by JCM were used for their culture. Cells were harvested in the late exponential phase, and genomic DNAs were prepared as described. ${ }^{71}$

Cloning of the Dam methylase gene and purification of the protein. The gene pot0847421 coding for Dam methylase was cloned from Pyrococcus sp. OT3 by using polymerase chain reactions, ${ }^{72)}$ and introduced into the pET15b vector under the T7 promoter. This plasmid was introduced into E. coli strain BL21 (DE3), and expression of the gene was induced using isopropyl-1-thio- $\beta$-D-galactopyranoside.

From the cell extract the Dam methylase of $P$. OT3 was purified. Some of the contaminating $E$. coli proteins were denatured by incubation at $70{ }^{\circ} \mathrm{C}$ for $30 \mathrm{~min}$ and removed. Some other contaminants were precipitated, when ammonium sulfate, $20 \%$ saturated, was added. The fraction further precipitated by increasing the ammonium sulfate concentration to $70 \%$ saturated was subjected to ion exchange chromatography using Q-sepharose (Pharmacia). Using a linear, $0.2-1 \mathrm{M}$, gradient of $\mathrm{KCl}$ in 50 mM HEPES buffer (pH 7.0), the fraction eluted with 0.4$0.5 \mathrm{M} \mathrm{KCl}$ was collected. Finally, Dam methylase from $P$. OT3 was purified by hydrophobic chromatography using Butyl-Toyopearl (TOSO) and a linear, 1.5-0M, gradient of ammonium sulfate in $10 \mathrm{mM}$ HEPES buffer (pH 7.0).

In vitro methylation of DNA by archaeal Dam methylase. The methylated and unmethylated forms of DNA were prepared by introducing the pUC18 plasmid into the strains JM109 $\left(\mathrm{dam}^{+}\right)$and JM110 ( $\left.\mathrm{dam}^{-}\right)$of $E$. coli ${ }^{29)}$ respectively. The purified Dam methylase of $P$. OT3, $1.5 \mu \mathrm{g} / \mathrm{ml}$, was incubated with the unmethylated form of pUC18, $150 \mathrm{\mu g} / \mathrm{ml}$, and $2 \mathrm{mM} S$-methyladenosylL-methionine in $50 \mathrm{mM}$ Tris-HCl buffer (pH 7.5) containing $10 \mu \mathrm{M}$ EDTA and $5 \mathrm{mM}$ 2-mercaptoethanol for 30 $\min$ at $75^{\circ} \mathrm{C}$.

Detection of methylation at GATC sites. Various DNAs, the plasmid DNAs treated or untreated with the archaeal Dam methylase or the genomic DNAs purified, $1 \mu \mathrm{g}$ each, were treated with 5-10 units of each restriction enzyme, Sau3AI, DpnI, or MboI (Boeringer Manheim) for $1 \mathrm{hr}$ at $37^{\circ} \mathrm{C}$, and subjected to electrophoresis using $1 \%$ agarose gels containing $40 \mathrm{mM}$ Trisacetate buffer ( $\mathrm{pH}$ 7.7) and $10 \mathrm{mM}$ EDTA. The gels were stained with $10 \mu \mathrm{g} / \mathrm{ml}$ ethidium bromide.

Melting temperature measurements. Synthetic oligomers of DNA in the methylated and intact forms were purchased from Bex Co. (Tokyo). The melting temperature, Tm, of DNA duplexes was determined in 20 mM Na-phosphate buffer ( $\mathrm{pH}$ 7.0) containing $100 \mathrm{mM}$ $\mathrm{NaCl}$ and $1 \mathrm{mM}$ EDTA by monitoring changes in circular dichroism or ultra violet absorption. ${ }^{22)}$ Some of the Tm values in Table II are slightly different from those reported earlier, ${ }^{22)}$ since the measurements have been repeated thereby determining averages and standard deviations. The other values are newly reported here.

Acknowledgements. We thank Mr. Naoki Amano for his help at early stages of this work. This work was supported by the CREST (Core Research for Evolutionary Science and Technology) program of JST (Japan Science and Technology Agency) in the research area PSFM (Protein Structure and Functional Mechanisms).

\section{References}

1) Dunn, D. B., and Smith, J. D. (1958) Biochem. J. 68, 627-636.

2) Marinus, M. G., and Morris, N. R. (1973) J. Bacteriol. 114, 1143-1150.

3) Marinus, M. G. (1987) Ann. Rev. Genet. 21, 113-131.

4) Messer, W., and Noyer-Weidner, M. (1988) Cell 54, 735-737.

5) Claverys, J. P., and Lacks, S. A. (1986) Microbiol. Rev. 50, 133-165.

6) Barras, F., and Marinus, M. G. (1989) Trends Genet. 5, 139-143.

7) Modrich, P. (1989) J. Biol. Chem. 264, 6597-6600.

8) Palmer, B. R., and Marinus, M. G. (1994) Gene 143, 1-12.

9) Crooke, E. (1995) Cell 82, 877-880.

10) Modrich, P., and Lahue, R. (1996) Ann. Rev. Biochem. 65, 101-133. 
11) Messer, W., Bellekes, U., and Lother, H. (1985) EMBO J. 4, 1327-1332.

12) Smith, D. W., Garland, A. M., Herman, G., Enns, R. E., Baker, T. A., and Zyskind, J. W. (1985) EMBO J. 4, 1319-1326.

13) Barbeyron, T., Kean, K., and Forterre, P. (1984) J. Bacteriol. 160, 586-590.

14) Lodwick, D., Ross, H. N. M., Harris, J. E., Almond, J. W., and Grant, W. D. (1986) J. Gen. Microbiol. 132, 3055-3059.

15) Baranyi, U., Klein, R., Lubitz, W., Krüger, D. H., and Witte, A. (2000) Mol. Microbiol. 35, 1168-1179.

16) Kawashima, T., Yamamoto, Y., Aramaki, H., Nunoshiba, T., Kawamoto, T., Watanabe, K., Yamazaki, M., Kanehori, K., Amano, N., Ohya, Y. et al. (1999) Proc. Jpn. Acad. Ser. B 75, 213-218.

17) Kawashima, T., Amano, N., Koike, H., Makino, S., Higuchi, S., Kawashima-Ohya, Y., Watanabe, K., Yamazaki, M., Kanehori, K,. Kawamoto, T. et al. (2000) Proc. Natl. Acad. Sci. USA 97, 14257-14262.

18) Ruepp, A., Graml, W., Santos-Martinez, M.-L., Koretke, K. K., Volker, C., Mewes, H. W., Frishman, D., Stocker, S., Lupas, A. N., and Baumeister, W. (2000) Nature 407, 508-513.

19) Fazakerley, G. V., Téoule, R., Guy, A., Fritzsche, H., and Guschlbauer, W. (1985) Biochemistry 24, 4540-4548.

20) Engel, J. D., and Von Hippel, P. H. (1974) Biochemistry 13, 4143-4158

21) Engel, J. D., and Von Hippel, P. H. (1978) J. Biol. Chem. 253, 927-934.

22) Yamasaki, T., Yamasaki, K., and Suzuki, M. (1998) Proc. Jpn. Acad. Ser. B 74, 210-215.

23) Gómez-Eichelmann, M. C. (1979) J. Bacteriol. 140, 574-579

24) Kawarabayasi, Y., Sawada, M., Horikawa, H., Haikawa, Y., Hino, Y., Yamamoto, S., Sekine, M., Baba, S., Kosugi, H., Hosoyama, A. et al. (1998) DNA Res. 5, 55-76.

25) Maeder, D. L., Weiss, R. B., Dunn, D. M., Cherry, J. L., González, J. M., DiRuggeiero, J., and Robb, F. T. (1999) Genetics 152, 1299-1305.

26) She, Q., Singh, R. K., Confalonieri, F., Zivanovic, Y., Allard, G., Awayez, M. J., Chan-Weiher, C. C.-Y., Clausen, I. G., Curtis, B. A., Moors, A. D. et al. (2001) Proc. Natl. Acad. Sci. USA 98, 7835-7840.

27) Ng, W. V., Kennedy, S. P., Mahairas, G. G., Berquist, B., Pan, M., Shukla, H. D., Lasky, S. R., Baliga, N. S., Thorsson, V., Sbrogna, J. et al. (2000) Proc. Natl. Acad. Sci. USA 97, 12176-12181.

28) Malone, T., Blumenthal, R. M., and Cheng, X. (1995) J. Mol. Biol. 253, 618-632.

29) Yanisch-Perron, C., Vieira, J., and Messing, J. (1985) Gene 33, 103-119.

30) Roberts, R. J., Vincze, T., Posfai, J., and Macelis, D. (2003) Nucl. Acids Res. 31, 418-420.

31) Bult, C. J., White, O., Olsen, G. J., Zhou, L., Fleischmann, R. D., Sutton, G. G., Blake, J. A., FitzGerald, L. M., Clayton, R. A., Gocayne, J. D. et al. (1996) Science 273, 1058-1073.

32) Smith, D. R., Doucette-Stamm, L. A., Deloughery, C., Lee, H.M., Dubois, J., Aldredge, T., Bashirzadeh, R., Blakely, D.,
Cook, R., Gilbert, K. et al. (1997) J. Bacteriol. 179, 7135-7155.

33) Klenk, H.-P., Clayton, R. A., Tomb, J.-F., White, O., Nelson, K. E., Ketchum, K., Dodson, R. J., Gwinn, M., Hickey, E. K., Peterson, J. D. et al. (1997) Nature 390, 364-370.

34) Kawarabayasi, Y., Hino, Y., Horikawa, H., Yamazaki, S., Haikawa, Y., Jin-no, K., Takahashi, M., Sekine, M., Baba, S., Ankai, A. et al. (1999) DNA Res. 6, 83-101.

35) Kawarabayasi, Y., Hino, Y., Horikawa, H., Jin-no, K., Takahashi, M., Sekine, M., Baba, S., Ankai, A., Kosugi, H., Hosoyama, A. et al. (2001) DNA Res. 8, 123-140.

36) Cohen, G. N., Barbe, V., Flament, D., Galperin, M., Heilig, R., Lecompte, O., Poch, O., Prieur, D., Querellou, J., Ripp, R. et al. (2003) Mol. Microbiol. 47, 1495-1512.

37) Mount, D. W. (2001) Bioinformatics: Sequence and Genome Analysis. Cold Spring Harbor Laboratory Press, New York.

38) Durban, R., Eddy, S., Krogh, A., and Mitchison, G. (1998) Biological sequence analysis. Cambridge University Press, Cambridge.

39) Fütterer, O., Angelov, A., Liesegang, H., Gottschalk, G., Schleper, C., Shepers, B., Dock, C., Antraniklian, G., and Liebl, W. (2004) Proc. Natl. Acad. Sci. USA 101, 9091-9096.

40) Hendrickson, E. L., Kaul, R., Zhou, Y., Bovee, D., Chapman, P., Chung, J., Conway de Macario, E., Dodsworth, J. A., Gillett, W., Graham, D. E. et al. (2004) J. Bacteriol. 186, 6965-6969.

41) Koike, H., Ishijima, S. A., Clowney, L., and Suzuki, M. (2004) Proc. Natl. Acad. Sci. USA 101, 2840-2845.

42) Suzuki, M. (2003) Proc. Jpn. Acad., Ser. B 79, 274-289.

43) Koike, H., Sakuma, M., Mikami, A., Amamo, N., and Suzuki, M. (2003) Proc. Jpn. Acad., Ser. B 79, 63-69.

44) Suzuki, M., Amano, N., and Koike, H. (2003) Proc. Jpn. Acad., Ser. B 79, 92-98.

45) Suzuki, M., and Koike, H. (2003) Proc. Jpn. Acad., Ser. B 79 , 114-119.

46) Suzuki, M. (2003) Proc. Jpn. Acad., Ser. B 79, 213-222.

47) Suzuki, M., Koike, H., and Aramaki, H. (2003) Proc. Jpn. Acad., Ser. B 79, 242-247.

48) Ishijima, S. A., Clowney, L., Koike, H., and Suzuki, M. (2003) Proc. Jpn. Acad., Ser. B 79, 299-304.

49) Ishijima, S. A., Clowney, L., Koike, H., and Suzuki, M. (2004) Proc. Jpn. Acad., Ser. B 80, 22-27.

50) Ishijima, S. A., Clowney, L., Koike, H., and Suzuki, M. (2004) Proc. Jpn. Acad., Ser. B 80, 107-113.

51) Clowney, L., Ishijima, S. A., and Suzuki, M. (2004) Proc. Jpn. Acad., Ser. B 80, 148-155.

52) Ishijima, S. A., Clowney, L., and Suzuki, M. (2004) Proc. Jpn. Acad., Ser. B 80, 183-188.

53) Ishijima, S. A., Clowney, L., and Suzuki, M. (2004) Proc. Jpn. Acad., Ser. B 80, 236-243.

54) Ishijima, S. A., Clowney, L., and Suzuki, M. (2004) Proc. Jpn. Acad., Ser. B 80, 459-468.

55) Sakuma, M., Koike, H., and Suzuki, M. (2005) Proc. Jpn. Acad., Ser. B 81, 26-32.

56) Yokoyama, K., Ebihara, S., Kikuchi, T., and Suzuki, M. (2005) 
Proc. Jpn. Acad., Ser. B 81, 64-75.

57) Sakuma, M., Nakamura, M., Koike, H., and Suzuki, M. (2005) Proc. Jpn. Acad., Ser. B 81, 111-117.

58) Yokoyama, K., and Suzuki, M. (2005) Proc. Jpn. Acad., Ser. B 81, 64-75.

59) Kawashima, T., Yokoyama, K., Higuchi, S., and Suzuki, M. (2005) Proc. Jpn. Acad., Ser. B 81, 204-219.

60) Yokoyama, K., Ishijima, S. A., Clowney, L., Koike, H., Aramaki, H., Tanaka, C., Makino, K., and Suzuki, M. (2005) FEMS Microbiol. Review (in press).

61) Kudo, N., Allen, M. D., Koike, H., Katsuya, Y., and Suzuki, M. (2001) Acta Cryst. D57, 469-471.

62) Cui, Y., Wang, Q., Stormo, G. D., and Calvo, J. M. (1995) J. Bacteriol. 177, 4872-4880.

63) Ouhammouch, M., and Geiduschek, E. P. (2001) EMBO J. 20, 146-156.

64) Suzuki, M. (1993) EMBO J. 12, 3221-3226.

65) Suzuki, M. (1994) Structure 2, 317-326.

66) Suzuki, M., and Yagi, N. (1994) Proc. Natl. Acad. Sci. USA 91, 12357-12361.

67) Pearson, W. R., and Lipman, D. L. (1988) Proc. Natl. Acad. Sci. USA 85, 2444-2448.

68) Koike, H., Amano, N., Tateno, M., Ohfuku, Y., Suckow, J. M., and Suzuki, M. (1999) Proc. Jpn. Acad., Ser. B 75, 37-42.

69) Becker, R. A., Chambers, J. M., and Wilks, A. R. (1988) The New S Language. Chapman \& Hall, London.

70) Higgins, D. G., Bleasby, A. J., and Fuchs, R. (1992) Comput. Appl. Biosci. 8, 189-191.
71) Ramakrishnan, V., and Adams, M. W. W. (1995) in Thermophiles (eds. Robb, F. T., and Place, A. R.) Cold Spring Harbor Laboratory Press, New York, USA., pp. 95-96.

72) Saiki, R. K., Gelfand, D. H., Stoffel, S., Scharf, S. J., Higuchi, R., Horn, G. T., Mullis, K. B., and Erlich, H. A. (1988) Science 239, 487-491.

73) Fukui, T., Atomi, H., Kanai, T., Matsumi, R., Fujiwara, S., and Imanaka, T. (2005) Genome Res. 15, 352-363.

74) Deppenmeier, U., Johann, A., Hartsch, T., Merkl, R., Schmitz, R. A., Martinez-Arias, R., Henne, A., Wiezer, A., Baumer, S., Jacobi, C. et al. (2002) J. Mol. Microb. Biotechnol. 4, 453-461.

75) Slesarev, A. I., Mezhevaya, K. V., Makarova, K. S., Polushin, N. N., Shcherbinina, O. V., Shakhova, V. V., Belova, G. I., Aravind, L., Natale, D. A., Rogozin, I. B. et al. (2002) Proc. Natl. Acad. Sci. USA 99, 4644-4649.

76) Baliga, N. S., Bonneau, R., Facciotti, M. T., Pan, M., Glusman, G., Deutsch, E. W., Shannon, P., Chiu, Y., Weng, R. S., Gan, R. R. et al. (2004) Genome Res. 14, 2221-2234.

77) Waters, E., Hohn, M. J., Ahel, I., Graham, D. E., Adams, M. D., Barnstead, M., Beeson, K. Y., Bibbs, L., Bolanos, R., Keller, M. et al. (2003) Proc. Natl. Acad. Sci. USA 100, 12984-12988.

(Received Aug. 23, 2005; accepted Sept. 12, 2005) 